\title{
A Complete Materials Service
}

A MONG THE MANY audio-visual units in the United States probably no two are identical because each must meet the special requirements of the parent institution. Thus, the functions of the Audio-Visual Center, Air University Library, are determined by the educational program of Air University. The library has as its mission the support of Air University with all types of instructional materials. Of these, the AudioVisual Center provides non-print materials such as films, maps and charts, graphic aids, photographic slides and prints, and audio aids.

Much has been said and written concerning the placement of audio-visual services within the organizational structure of an educational institution. A logical conclusion seems to indicate placement for the greatest possible effectiveness. For Air University the library is the most logical location. This organization has established high standards for rendering specialized service. The administration of the library not only realizes the values of having all instructional materials and services combined, but is prepared to render full support to the audio-visual as well as the traditional elements. Fully recognized is the principle of having each special type of service directed by competent professionals with adequate training and experience. At the time the audio-visual services were placed in the library, plans were under way for a building to be located in the center of a new campus. Adequate space was designed in the new building to meet the needs of audio-visual services. Also es-

Dr. Mitchell is chief, Audio-Visual Center, Air University Library.

tablished in the library is a pattern for financing and procurement so essential for the operation of audio-visual services. It has its own supply unit capable of procuring special non-military as well as the usual military supplies and equipment. For Air University the library as an organization dedicated to giving only the best in service and materials provides a natural environment for the Audio-Visual Center.

The Audio-Visual Center is directed by two professional audio-visual educators who supervise the operation of the organization, advise instructors and school administrators, maintain liaison with other military schools, civilian institutions, business and industry, and conduct a program of evaluation, experimentation, and research. This organization serves Air University as its primary agency for the evaluation, selection, procurement, production, storage, maintenance, distribution, and utilization of a wide variety of audio-visual materials.

One of the services most commonly associated with an audio-visual organization is a film library. The Center's Branch Film Exchange is one of three of that category in the United States. The others are at the Air Force Academy and the Pentagon. The Exchange is a unit within the Air Force system of film distribution. Because of the nature of the Air University curriculum, the Exchange not only receives automatically all Air Force films but exploits short-term loans from other military libraries, civilian rental sources, and industrial collections. Occasionally it locates and procures kinescopes of outstanding television programs which are used for classroom instruction. In addition to a two thousand-print library of 
films, the Exchange maintains a collection of slide sets, filmstrips, and still pictures. Although the Branch does provide equipment and projection service, its greatest screening activity is in its preview rooms. Instructors and students frequently view films as reference materials in preparation of lectures or special studies. Maintenance of materials and equipment is comparable to other film libraries. More specialized is its professional service in locating and procuring special films, kinescopes, and still pictures from a wide variety of sources. Many of the desired items are not widely distributed, and diligent search is often needed to meet unusual requirements.

Unique as a part of an audio-visual service is the Cartographic Branch, which combines professional assistance and an extensive collection of some six thousand different titles of maps and charts totaling approximately 250,000 sheets. The cartographers work with both instructors and students in all types of problems involving the use of maps and charts. At times, a map or chart must be modified to illustrate particular physical, political, economic, or other facts. In such cases the cartographers modify existing material or draw up specifications for a new issue. The Air Force Physical-Political Global Chart is an example of such a project.

In addition to the Aeronautical Chart and Information Center, the Branch draws upon the services of Army Map Service, Hydrographic Office, Coast and Geodetic Survey, Geological Survey, National Geographic Society, and a number of commercial agencies. Because of the need for the most up-to-date information, the collection is checked constantly to insure that each item is the most recent issue. All charts are analyzed, indexed, and filed systematically for instant recovery when needed.

The Center has two Graphics Branches with one at Maxwell Air Force Base and the other at Gunter Air Force Base. Each produces a wide variety of instructional and briefing materials such as charts, graphs, maps, murals, models, heraldic emblems, certificates, sketches, book and manual illustrations, and masters for transparencies of various sizes. Most of the production of these Branches is concerned with custom designed and executed training aids. The instructor presents his requirement for analysis and visualization by artists who specialize in this aspect of the work. Once the sketches are approved, a production crew completes the graphic representation.

Some materials require further processing after the completion of art work. Slide masters may be sent to the Photographic Laboratory for conversion to transparencies in color or in black and white and in any of the standard sizes of two by two inches, three and a quarter by four inches, or eight by ten inches. Many overhead transparencies are prepared on tracing paper for reproduction by the diazo process.

Although most charts are prepared on board thirty by forty inches or smaller, for auditorium use they may be twenty to thirty feet long and up to ten feet high. Recently a nine by forty foot mural depicting air evacuation was produced. Graphics personnel work with all types of media, depending only on which medium will be most effective.

The products of the two Graphics Branches differ somewhat because of the nature of the colleges and schools served. The Gunter Branch is primarily concerned with materials illustrating phases of aviation medicine for use in the School of Aviation Medicine. The Maxwell Branch produces aids for the better illustration of administration, command, and air power problems since it serves Headquarters Air University, Air War College, Air Command and Staff Col- 
lege, and Air Force Reserve Officers Training Corps.

The Photographic Laboratory of the Audio-Visual Center provides three types of photographic reproduction: microfilm, photostat, and transparencies. The Microfilm Section is fully equipped to produce $35 \mathrm{~mm}$. and $16 \mathrm{~mm}$. film in both negative and positive. It has planetary and rotary cameras, printers, continuous processors, and editing equipment. The principal purpose in microfilming is the reduction of the Air University Library's extensive document collection to film. Approximately six thousand feet of microfilm are shot each month. The negative file remains in the laboratory for ready reproduction. Positive prints are filed in the reading room for use by instructors and students.

The Photostat Section produces direct positive copy up to the size of seventeen by twenty-two inches from original copy or microfilm. Present production averages four thousand full sheets each month. This laboratory provides proportional enlargement or reduction of copy for the Graphic Branches. The direct positive photostat also serves as a satisfactory master for the reproduction of copies by the diazo process.

The third and newest section of the laboratory produces transparencies and prints for instructional purposes. These are made in black and white or color, in sizes varying from two by two inches to eight by ten inches. Although most of the original material is art layout produced by the Graphics Branches, some slides may be location shots or the reproduction of prints or slides as needed by the instructor. Photographic prints are also produced to illustrate training manuals and reports.

The Reproduction Section is a very small unit with a relatively important function. It produces by mimeograph or multilith a wide variety of visual materials. A major product is catalog cards, of which fifteen thousand are printed each month. Another activity of the Section is the offset printing of special bibliographies prepared by reference personnel of the library for up-to-theminute information on current documents, periodical articles, and books pertinent to the special interest areas of students and instructors.

The services of the Audio-Visual Center are constantly evaluated in terms of the curriculum requirements of Air University. During the past two years considerable time and effort have been devoted to the analysis of organization, housing, personnel, materials, equipment, and procedures in order to determine ways and means of improving the services. These efforts have led to more effective coordination, better working conditions, more efficient production, higher morale of staff members, and better quality instructional aids. The Center exists solely for the purpose of assisting the instructors to do a more effective job of communicating with their students. Future modifications of the Center will be determined by the requirements of the instructional program of Air University.

"Do you want facts? Want to prove something? Trying to find yourself, or the opposite, escape from yourself? We've got books for all purposes, for yes and no, for good and bad, black and white, near and far, for and against. . . . It's not for sale, it's for free-this place with something for every student, hurried or not, this intellectual free-for-all called the Library, which finds the books of all times, races, colors, and creeds, stacked peacefully together under one roof."-Lawrence Clark Powell in Know Your Library (UCLA, 1957). 